\title{
Toll-like receptor 4 and NOD2/CARD15 mutations in Hungarian patients with Crohn's disease: Phenotype-genotype correlations
}

\author{
Peter Laszlo Lakatos, Laszlo Lakatos, Ferenc Szalay, Claudia Willheim-Polli, Christoph Österreicher, Zsolt Tulassay, \\ Tamas Molnar, Walter Reinisch, Janos Papp, Gyula Mozsik, Hungarian IBD Study Group, Peter Ferenci
}

Peter Laszlo Lakatos, Ferenc Szalay, Janos Papp, Hungarian IBD Study Group, 1st Department of Medicine, Semmelweis University, Budapest, Hungary

Laszlo Lakatos, 1st Department of Medicine, Csolnoky F. County Hospital, Veszprem, Hungary

Claudia Willheim-Polli, Christoph Österreicher, Walter Reinisch, Peter Ferenci, Department of Internal Medicine 4, University of Vienna, Austria

Zsolt Tulassay, 2nd Department of Medicine, Semmelweis University, Budapest, Hungary

Tamas Molnar, 1st Department of Medicine, University of Szeged, Szeged, Hungary

Gyula Mozsik, 1st Department of Medicine, University of Pecs, Pecs, Hungary

Hungarian IBD Study Group: Semmelweis University, 1st Department of Medicine, Budapest: Peter Fuszek, Peter Vargha; Semmelweis University, 2nd Department of Medicine, Semmelweis University, Budapest: Laszlo Pronait, Annamaria Nemeth, Pal Miheller; Erzsebet Hospital, 1st Department of Medicine, Budapest: Agota Kovacs, Laszlo Bene; Szent Janos Hospital, 1st Department of Medicine: Gyorgy Szekely; University of Pecs, 1st Department of Medicine, Pecs: Beata Gasztonyi; University of Szeged, 1st Department of Medicine, Szeged: Ferenc Nagy, Janos Lonovics; Semmelweis Hospital, 1st Department of Medicine, Miskolc: Laszlo Ujszaszy; University of Debrecen, 2nd Department of Medicine, Debrecen: Istvan Altorjai, Karoly Palatka; Kenezi Gy. County Hospital, 2nd Department of Medicine, Debrecen: Gyula G. Kiss; County Hospital, 2nd Department of Medicine, Zalaegerszeg; Ferenc Tarnok, Markusovszky Hospital, 2nd Department of Medicine, Szombathely: Zoltan Dobronte; Csolnoky F. County Hospital, 1st Department of Medicine, Veszprem: Zsuzsanna Erdelyi, Tunde Pandur, Gabor Mester

Correspondence to: Peter Laszlo Lakatos, M.D., Ph.D., 1st Department of Medicine, Semmelweis University, Koranyi str. 2/A, H-1083, Hungary. kislakpet@bel1.sote.hu

Telephone: +36-1-210-0278/1500-1520 Fax: +36-1-313-0250

Received: 2004-07-26 Accepted: 2004-09-09

\section{Abstract \\ AIM: To determine common NOD2/CARD15 mutations and TLR4 D299G polymorphism in Hungarian patients with CD.}

METHODS: A total of 527 unrelated patients with CD (male/female: 265/262, age: 37.1 (SD 7.6) years) and 200 healthy subjects were included. DNA was screened for possible NOD2/CARD15 mutations by denaturing highperformance liquid chromatography (confirmed by direct sequencing). TLR4 D299G was tested by PCR-RFLP.

RESULTS: NOD2/CARD15 mutations were found in 185 patients $(35.1 \%)$ and in 33 controls $(16.5 \%, P<0.0001)$. SNP8/R702W (10.8\% vs $6 \%, P=0.02)$, SNP13/3020insC $(19.4 \%$ vs $5 \%, P<0.0001)$ and exon4 R703C $(2.1 \%$ vs $0 \%, P=0.02$ ) mutations were more frequent in $\mathrm{CD}$, while the frequency of SNP12/G908R was not increased. The frequency of TLR4 D299G was not different (CD: $9.9 \%$ vs controls: $12.0 \%$ ). Variant NOD2/CARD15 allele was associated with an increased risk for $\mathrm{CD}\left(\mathrm{OR}_{\text {het }}=1.71\right.$, $95 \% \mathrm{CI}=1.12-2.6, P=0.0001, \mathrm{OR}_{\text {two-risk alleles }}=25.2$, $95 \% \mathrm{CI}=4.37-\quad, P<0.0001$ ), early disease onset (carrier: 26.4 years vs non-carrier: 29.8 years, $P=0.0006$ ), ileal disease $(81.9 \%$ dos $69.5 \%, \mathrm{OR}=1.99,95 \% \mathrm{CI}=1.29-3.08$, $P=0.02$, presence of NOD2/CARD15 and TLR4: $86.7 \%$ vs $64.8 \%)$, stricturing behavior $(\mathrm{OR}=1.69,95 \% \mathrm{CI}=1.13-2.55$, $P=0.026)$ and increased need for resection $(\mathrm{OR}=1.71$, 95\%CI: $1.13-2.62, P=0.01$, but not with duration, extraintestinal manifestations, familial disease or smoking. TLR4 exhibited a modifier effect: age of onset in wt/TLR4 D299G carriers: 27.4 years vs NOD2mut/TLR D299G: 23 years $(P=0.06)$, in NOD2mut/wt: 26.7 years.

CONCLUSION: These results confirm that variant NOD2/ CARD15 (R702W, R703C and 3020insC) alleles are associated with earlier disease onset, ileal disease, stricturing disease behavior in Hungarian CD patients. In contrast, although the frequency of TLR4 D299G polymorphism was not different from controls, NOD2/TLR4 mutation carriers tended to present at earlier age.

(c) 2005 The WJG Press and Elsevier Inc. All rights reserved.

Key words: Crohn's disease; NOD2; CARD15; TLR4; Extraintestinal manifestation; Phenotype

Lakatos PL, Lakatos L, Szalay F, Willheim-Polli C, Österreicher C, Tulassay Z, Molnar T, Reinisch W, Papp J, Mozsik G, Hungarian IBD Study Group, Ferenci P. Toll-like receptor 4 and NOD2/CARD15 mutations in Hungarian patients with Crohn's disease: Phenotype-genotype correlations. World J Gastroenterol 2005; 11(10): 1489-1495

http://www.wjgnet.com/1007-9327/11/1489.asp

\section{INTRODUCTION}

Inflammatory bowel disease (IBD) is a multifactorial polygenic disease with probable genetic heterogeneity. In addition to genetic predisposition, various environmental and host factors (e.g. genetic, epithelial, immune and nonimmune factors) play a major role in the pathogenesis of IBD. Crohn's disease (CD) is a chronic inflammatory disorder of the gastrointestinal tract. Extensive heterogeneity is observed in terms of disease presentation, behavior, and response to treatment ${ }^{[1,2]}$. Attempts have been made to define clinical subgroups on the basis of age at onset, disease location, extent (diffuse or localized) and behavior (primary 
inflammatory, fistulating, or fibrostenotic).

$\mathrm{CD}$ has a strong genetic component, with a lifetime risk of $10-20 \%$ to develop IBD in the presence of an affected first-degree relative ${ }^{[1]}$. The concordance rate of affected siblings for age at onset, disease site, behavior and presence of extra-intestinal manifestation is as high as $80 \%$. Since the first report of Hugot et al. ${ }^{[3]}$ in 1996, seven IBD loci have been identified on chromosomes 16q12 (IBD1), 12q13 (IBD2), 6p13 (IBD3), 14q11 (IBD4), 5q31-33 (IBD5), $19 \mathrm{p} 13$ (IBD6) and $1 \mathrm{p}$ (IBD7) ${ }^{[4-6]}$. These seven loci are convincingly replicated. Some genetic markers increase the risk of ulcerative colitis or CD while others are associated with a particular phenotypic expression like disease location and/or behavior. The NOD2/CARD15 gene is located in the IBD1 region. NOD2/CARD15 is a cytoplasmatic protein expressed in peripheral blood monocytes, Paneth cells and intestinal epithelial cells and is related structurally to the welldescribed $\mathrm{R}$ proteins in plants, which mediate host resistance to microbial pathogens ${ }^{[7]}$ and induce the NF- $\kappa$ B pathway ${ }^{\left[{ }^{[8]}\right.}$. Variant alleles result in reduced $\mathrm{NF}-\kappa \mathrm{B}$ activity ${ }^{[9]}$. Variant NOD2/CARD15 alleles are also associated with reduced $\alpha$-defensin release from Paneth cells in response to bacteria ${ }^{[10]}$. Of particular importance is the $\mathrm{C}$-terminus leucine-rich repeat domain, reportedly the major structural motif that functions as a pattern-recognition receptor for broad types of microbial components, such as bacterial lipopolysaccharides (LPS) and peptidoglycan (including MDP) ${ }^{[11]}$.

Two single nucleotide polymorphisms of NOD2/ CARD15 (SNP8: Arg702Trp and SNP12: Gly908Arg) and a frame shift mutation (SNP13: Leu1007insC) have been shown by three independent groups to be associated with susceptibility to $\mathrm{CD}^{[12-14]}$. The presence of one variant allele increases the risk for developing CD 1.5-4.3-fold, and the presence of two copies up to $20-40-$ fold $^{[13-15]}$. It has also been suggested that the presence of variant alleles is associated with ileal disease and fibrostenosing or fistulizing behavior in some $e^{[15,16]}$, but not in all the studies ${ }^{[17,18]}$.

However, there are significant geographical differences in the frequency of these alleles. They are not found in Japan and China ${ }^{[19,20]}$ and are less frequent in Finland ${ }^{[21]}$ than in Western Europe. There are only limited data in patients from Central-Eastern European countries like Hungary. The incidence of CD in Hungary has been steadily elevat in the last decades (from 0.41 in 1977-1981 to 4.68 in 1997-2001), now reaching that of Western European countries.

Toll-like receptors (TLRs) expressed in myeloid cells play a major role both in detecting microbes and in initiating innate immune responses. In contrast, little is known concerning the expression, distribution and function of TLRs in epithelial cells per se. Toll-like receptor 4 (TLR4) is also expressed in the Golgi apparatus of intestinal epithelial cells. Thus, LPS recognition in intestinal epithelial cells may occur in the Golgi apparatus and require LPS internalization ${ }^{[22]}$. Recently it has been suggested that the interaction of LPS with TLR4/MD2 contributes to the perpetuation of the inflammatory epithelial cell injury via TNF $\alpha$-induced alterations of enterocyte turnover in an autoparacrine/ paracrine manner ${ }^{[23]}$. TLRs may also influence the nature of the immune response, in particular by skewing $\mathrm{T}$ cells toward a Th1 or Th2 profile. Myeloid cells are exquisitely sensitive to TLR ligands and produce significant IL-12p40 and appear to play key roles in the initiation and possibly the Th1/Th2 skewing of inflammatory responses. In this model the inflammation would normally be controlled by myeloid or lymphocyte-derived IL-10 acting through Stat3 in myeloid cells to block further production of IL-12/IL23 and skewing to Th1 response ${ }^{[24]}$.

TLR4 is upregulated in the intestinal epithelial cells in patients with CD. In contrast, the expressions of TLR2 and TLR5 are unchanged, while TLR3 is down-regulated ${ }^{[25]}$. The D299G (Asp299Gly) polymorphism of TLR4 gene is associated with LPS hyporesponsiveness ${ }^{[26]}$ and recently an association between TLR4 mutation and CD was reported in one study ${ }^{[27]}$, but not in another ${ }^{[28]}$.

In view of the limited data on the prevalence of NOD2/CARD15 mutations in Eastern European countries, our aim was to investigate the presence of the common three and other exon4 variants of NOD2/CARD15 as well as the presence of functional D299G polymorphism of the TLR4 gene in three large cohorts of Hungarian patients with CD. We also aimed to investigate the possible association between genotype and clinical characteristics of the disease.

\section{MATERIALS AND METHODS Patients}

A total of 527 unrelated Hungarian patients with CD [male/ female: 265/262, age: 37.1 (SD 7.6) years] were investigated. The patients were recruited from three Hungarian IBD centers (Szeged [ $n=167]$, Budapest [ $n=185]$, Veszprem $[n=175])$. CD patients, with a follow-up time of at least one year were included. The diagnosis was based on the Lennard-Jones criteria ${ }^{[29]}$. The clinical characteristics of the patients are summarized in Table 1. The disease phenotype

Table 1 Clinical characteristics of the different cohorts of Crohn's disease (CD) patients

\begin{tabular}{|c|c|c|c|c|}
\hline & & $\begin{array}{c}\text { Budapest } \\
(n=185)\end{array}$ & $\begin{array}{r}\text { Veszprem } \\
\quad(n=175)\end{array}$ & $\begin{array}{l}\text { Szeged } \\
(n=167)\end{array}$ \\
\hline \multicolumn{2}{|l|}{ Male/Female } & $98 / 87$ & $88 / 87$ & $79 / 88$ \\
\hline \multicolumn{2}{|l|}{ Age (yr) } & $35.6 \pm 11.4$ & $37.8 \pm 13.3$ & $37.1 \pm 12.7$ \\
\hline \multicolumn{2}{|c|}{ Age at presentation (yr) } & $27.2 \pm 10.3$ & $30.2 \pm 12.4$ & $28.9 \pm 10.9$ \\
\hline \multicolumn{2}{|l|}{ Duration (yr) } & $8.9 \pm 6.6$ & $7.7 \pm 6.8$ & $8.0 \pm 7.3$ \\
\hline \multicolumn{2}{|c|}{ Familial IBD, $n(\%)$} & $63(11.9)$ & $38(11.1)$ & $25(13.5)$ \\
\hline \multirow[t]{4}{*}{ Location $(n)$} & L1 & 43 & 54 & 39 \\
\hline & L2 & 37 & 47 & 52 \\
\hline & L3 & 103 & 74 & 74 \\
\hline & $\mathrm{L} 4$ & 2 & 0 & 2 \\
\hline \multirow[t]{3}{*}{ Behavior $(n)$} & B1 & 88 & 65 & 62 \\
\hline & B2 & 40 & 39 & 49 \\
\hline & B3 & 56 & 71 & 56 \\
\hline \multicolumn{2}{|c|}{ Perianal disease, $n(\%)$} & $41(22.1)$ & $49(28.0)$ & $50(29.9)$ \\
\hline \multicolumn{2}{|c|}{ Frequent relapse, $n(\%)$} & $59(31.9)$ & $72(41.1)$ & $64(38.6)$ \\
\hline \multicolumn{2}{|c|}{$\begin{array}{l}\text { Extraintestinal } \\
\text { manifestations, } n(\%)\end{array}$} & $67(36.2)$ & $61(34.8)$ & $47(28.2)$ \\
\hline \multicolumn{2}{|c|}{ Operation, $n(\%)$} & 77 (41.6) & $76(43.4)$ & $67(40.1)$ \\
\hline \multicolumn{2}{|c|}{ Smoking habits $(n)$ No } & 115 & 96 & 98 \\
\hline & Yes & 55 & 61 & 55 \\
\hline & Previous & 15 & 20 & 14 \\
\hline
\end{tabular}


(age at onset, duration, location and behavior) was determined according to the Vienna classification ${ }^{[30]}$. Perianal involvement, presence of extraintestinal manifestations (EIM; arthritis: peripheral and axial; ocular manifestations: conjunctivitis, uveitis, iridocyclitis; skin lesions: erythema nodosum, pyoderma gangrenosum; hepatic manifestations: primary sclerosing cholangitis [PSC]), frequency of flare-ups (frequent flare-up: $>1$ /year), therapeutic effectiveness (e.g. steroid and/or immunosuppressive resistance), need for surgery (resections). Presence of familial IBD and smoking habits were investigated by filling in a questionnaire.

The control group for mutation analysis consisted of 200 age- and gender-matched healthy subjects [male/female: 102/98, age: 38.05 (SD 10.7) years]. The study was approved by the Semmelweis University Regional and Institutional Committee of Science and Research Ethics (81/2003). Each patient was informed of the nature of the study and signed the informed consent form.

\section{Detection of NOD2/CARD15 SNP8, 12, 13 and exon4 mutations}

Genomic DNA was isolated from whole blood according to the QIAamp DNA blood mini kit (QIAGEN GmbH, Germany). Each exon was amplified by PCR using previously published primer sequences ${ }^{[17]}$. The initial denaturation step (at $94{ }^{\circ} \mathrm{C}$ for $7 \mathrm{~min}$ ) was to activate AmpliTaq Gold (Applied Biosystems, Foster City, CA, USA), followed by 33 cycles (at $94{ }^{\circ} \mathrm{C}$ for $20 \mathrm{~s}$, at $61{ }^{\circ} \mathrm{C}$ for $30 \mathrm{~s}$, at $72{ }^{\circ} \mathrm{C}$ for $25 \mathrm{~s}$ ) with a final extension step at $72{ }^{\circ} \mathrm{C}$ for $7 \mathrm{~min}$. Then denaturing high-performance liquid chromatography (dHPLC, wave DNA fragment analysis system, Transgenomic Limited, UK) were performed to analyze the exons. PCR products were denatured as a last step at $94{ }^{\circ} \mathrm{C}$ for 5 min to induce heteroduplex formation during the following $30 \mathrm{~min}$ of slowly cooling down to room temperature. Five microliters of these PCR products were then automatically loaded onto the DNASep cartridge (Transgenomic Limited, UK) in the wave system. The specific acetonitrile gradient to elute each exon was established by using the WaveMaker 3.4.4 software. The particular run temperature for the detection of each SNP was determined using positive controls, which were kindly provided by Dirk Seegert from Kiel, Germany.

Finally, when a sequence variation was observed in the dHPLC profile, the relevant PCR product was sequenced on both strands to confirm the alteration. Sequencing reactions were performed with the $\mathrm{ABI} B \mathrm{BigDye}$ terminator cycle sequencing kit v1.1 (Applied Biosystems) and samples were sequenced on an ABI Prism 310 genetic analyzer (Applied Biosystems).

\section{Detection of TLR4 D299G polymorphism}

The TLR4 D299G polymorphism was detected by PCRRFLP (PTC-200 thermocycler, MJ Research Inc., MA, USA) using previously published primers and conditions ${ }^{[31]}$. For the overnight digestion of the amplified DNA, NcoI enzyme (New England Biolabs, London, UK) was used and the fragments were separated and visualized by gel electrophoresis (3\% NuSieve ${ }^{\circledR}$ GTG agarose gel BMA, Rockland, ME, USA).

\section{Statistical analysis}

Variables were tested for normality by Shapiro Wilk's $W$ test. $t$-test with separate variance estimates, $\chi^{2}$-test and $\chi^{2}$-test with Yates correction were used to test differences between patients with CD and controls, and also within subgroups of CD patients. Odds ratios (OR) and logistic regression were calculated to compare genetic and clinical data. $P<0.05$ was considered statistically significant. For the statistical analysis, Statistica 6.1 (Statsoft Inc., OK, USA) was used.

\section{RESULTS}

NOD2/CARD15 mutations were more frequently found in CD patients $(185 / 527 ; 35.1 \%)$ than those in controls $(16.5 \%, P<0.0001$, Table 2$)$. Heterozygous $\left(\mathrm{OR}_{\text {het }}=1.71\right.$; $95 \% \mathrm{CI}=1.12-2.6, P=0.0001)$, homozygous $\left(\mathrm{OR}_{\mathrm{hom}}=14.43\right.$; $95 \% \mathrm{CI}=2.47-\infty, P=0.0003)$ or compound heterozygous $\left(\mathrm{OR}_{\text {compound }}=12.92 ; 95 \% \mathrm{CI}=2.2-\infty, P=0.0006\right)$ carriage of a variant allele was associated with increased risk for CD. The OR for carrying two variant alleles was 25.2 (95\%CI: $4.35-\infty, P<0.0001)$. SNP8 (11.6\% vs controls: $6 \%)$ and SNP13 (19.4\% vs controls: 5\%, P<0.0001) mutations were more frequent in CD (Table 3), while the frequency of SNP12 variant allele was not different, but consistent in different cohorts (Table 4). The carriage of SNP8, SNP13 $\left(\mathrm{OR}_{\mathrm{SNP} 8 \text { allele }}=2.41 ; 95 \% \mathrm{CI}=1.30-4.44\right.$, $\left.\mathrm{OR}_{\mathrm{SNP} 13 \text { allele }}=4.78 ; 95 \% \mathrm{CI}=2.50-9.11\right)$ and a further exon 4 variant allele $\left(\mathrm{R} 703 \mathrm{C}_{\mathrm{CD}}: 2.1 \%\right.$ vs controls: $0 \%$, OR = 6.89; $95 \% \mathrm{CI}=1.18-\infty, P=0.02)$ were identified as risk factors for CD (Tables 3 and 5).

Table 2 NOD2/CARD15 and TLR4 D299G genotype in patients with Crohn's disease (CD) and controls, $n$ (\%)

\begin{tabular}{|c|c|c|c|c|c|}
\hline \multirow{2}{*}{ A } & \multicolumn{5}{|c|}{ NOD2 genotype } \\
\hline & Non-carrier & All carrier & Heterozygous & Homozygous & Compound heterozygous \\
\hline Controls $(n=200)$ & $167(83.5)$ & $33(16.5)$ & $33(16.5)$ & 0 & 0 \\
\hline $\mathrm{CD}(n=527)$ & $342(64.9)$ & $185(35.1)$ & $133(25.2)^{1}$ & $30(5.7)^{2}$ & $26(4.9)^{3}$ \\
\hline \multirow{2}{*}{ B } & \multicolumn{5}{|c|}{ TLR4 D299G } \\
\hline & Non-carrier & & All carrier & Heterozygous & Homozygous \\
\hline Controls $(n=200)$ & $176(88.0)$ & & $24(12.0)$ & $23(11.5)$ & $1(0.5)$ \\
\hline $\mathrm{CD}(n=527)$ & $475(90.1)$ & & $52(9.9)$ & $50(9.5)$ & $2(0.4)$ \\
\hline
\end{tabular}

$P<0.0001$ between CD patients and controls, ${ }^{1} \mathrm{OR}_{\text {het }}=1.71(1.12-2.60),{ }^{2} \mathrm{OR}_{\mathrm{hom}}=14.43(2.47-\infty),{ }^{3} \mathrm{OR}$ $=12.92(2.2-\infty)$. 
Table 3 NOD2/CARD15 SNP8, 12 and 13 in patients with Crohn's disease (CD) and controls

\begin{tabular}{|c|c|c|c|c|c|c|}
\hline & \multicolumn{2}{|c|}{ R702W (SNP8) ${ }^{1}$} & \multicolumn{2}{|c|}{ G908R (SNP12) } & \multicolumn{2}{|c|}{ 3020insC (SNP13) ${ }^{1}$} \\
\hline & $\mathrm{CD} n(\%)$ & Controls $n(\%)$ & $\mathrm{CD} n(\%)$ & Controls $n(\%)$ & $\mathrm{CD} n(\%)$ & Controls $n(\%)$ \\
\hline Wild type & $466(88.4)$ & $188(94.0)$ & $494(96.7)$ & $193(96.5)$ & $425(80.6)$ & $190(95.0)$ \\
\hline Heterozygous & $45(8.5)$ & $12(6.0)$ & $33(6.3)$ & $7(3.5)$ & 89 (16.9) & $10(5.0)$ \\
\hline Homozygous & $16(3.1)$ & 0 & 0 & 0 & $13(2.5)$ & 0 \\
\hline
\end{tabular}

${ }^{1} P=0.02$ and $P<0.0001$ between patients and controls for genotype frequency by $\chi^{2}$-test, $\mathrm{OR}_{\mathrm{SNP} 8 \text { allele }}=2.41(1.30-4.44), \mathrm{OR}$ SNP13 allele $=4.78(2.50-9.11)$.

Table 4 NOD2/CARD15 and TLR4 D299G mutations in different cohorts of CD patients, $n(\%)$

\begin{tabular}{llll}
\hline & $\begin{array}{c}\text { Budapest } \\
(n=185)\end{array}$ & $\begin{array}{c}\text { Veszprem } \\
(n=175)\end{array}$ & $\begin{array}{l}\text { Szeged } \\
(n=167)\end{array}$ \\
\hline NOD2/CARD15 & $64(34.6)^{1}$ & $61(34.9)^{1}$ & $60(35.9)^{1}$ \\
SNP8 & $17(9.2)$ & $23(13.1)^{2}$ & $21(12.6)^{3}$ \\
SNP12 & $12(6.5)$ & $10(5.7)$ & $11(6.6)$ \\
SNP13 & $39(21.1)^{1}$ & $33(18.9)^{1}$ & $30(18.0)^{4}$ \\
TLR4 D299G & $21(11.4)$ & $20(11.4)$ & $11(6.6)$ \\
\hline
\end{tabular}

${ }^{1} P<0.0001,{ }^{2} P=0.0002,{ }^{3} P=0.0005,{ }^{4} P=0.04$ cohort $v$ s controls (Tables 2,3 ).

Table 5 Further exon 4 mutations in patients with Crohn's disease (CD) and controls

\begin{tabular}{lcc}
\hline & $\mathrm{CD}(n=527)$ & Controls $(n=200)$ \\
\hline R703C & & \\
R713C & 11 (1 homozygous) & 0 \\
A755V & 1 & 0 \\
E778K & 2 & 1 \\
R791Q & 0 & 1 \\
V793M & 5 & 1 \\
& 2 & 1
\end{tabular}

${ }^{1} P=0.02$ between patients and controls for allele frequency, $\mathrm{OR}_{\mathrm{R} 703 \mathrm{C}}=6.89(1.18-\infty)$.
More homozygous $(60 \%)$ or compound heterozygous $(69.2 \%)$ patients tended to be females compared to heterozygous $(46.6 \%)$ patients and non-carriers $(49.1 \%)$. The use of immunosuppressive drugs $(P=0.04)$ and the need for surgery (resection, $P=0.006$ ) were more frequent in carriers of the mutation (Table 6). The percentage of patients with resection was even higher in compound heterozygous patients $(65.4 \%, 17 / 26, P=0.006$ compared to non-carriers by Fischer exact test). The presence of variant NOD2/CARD15 allele affected disease phenotype and was associated with earlier disease onset $(26.4$ vs 29.8 years, $P=0.0006$ ), the site of involvement (ileal involvement: $81.6 \%$ vs non-carriers: $69.0 \%, \mathrm{OR}=1.99,95 \% \mathrm{CI}: 1.29-3.08$, $P=0.02)$ and with stricturing behavior (OR $=1.69,95 \% \mathrm{CI}$ : $1.13-2.55, P=0.02$, Tables 6,7$)$. The presence of NOD2/ CARD15 variant alleles was not associated with the presence of perianal manifestation associated disease duration, more frequent relapses, familial disease and presence of EIMs or smoking habits. EIMs were tendentiously even less frequent in patients carrying two mutant alleles.

Table 6 Clinical characteristics of CD patients, with respect to the presence or absence of NOD2/CARD15 mutations

\begin{tabular}{|c|c|c|c|c|c|c|}
\hline & & Total $(n=527)$ & Non carrier $(n=342)$ & Carrier $(n=185)$ & 1 allele $(n=133)$ & 2 alleles $(n=52)$ \\
\hline \multicolumn{2}{|l|}{ Male/Female } & $265 / 262$ & $174 / 168$ & $91 / 94$ & $71 / 62$ & $20 / 32$ \\
\hline \multicolumn{2}{|l|}{ Age (yr) } & $36.9 \pm 9.1$ & $37.9 \pm 13.0$ & $34.9 \pm 11.6^{1}$ & $35.2 \pm 11.7$ & $34.3 \pm 11.4$ \\
\hline \multicolumn{2}{|c|}{ Age at presentation (yr) } & $37.1 \pm 7.6$ & $29.8 \pm 12.1$ & $26.4 \pm 9.7^{1}$ & $26.4 \pm 9.6$ & $26.5 \pm 10.2$ \\
\hline \multicolumn{2}{|c|}{ Duration (yr) } & $8.2 \pm 5.0$ & $8.1 \pm 7.0$ & $8.5 \pm 6.7$ & $8.8 \pm 7.0$ & $7.9 \pm 5.8$ \\
\hline \multicolumn{2}{|c|}{ Familiar IBD $n(\%)$} & $63(11.9)$ & $38(11.1)$ & 25 (13.5) & $17(12.8)$ & $8(15.4)$ \\
\hline \multirow[t]{3}{*}{ Location $(n)$} & L1 & 136 & 84 & $52^{1}$ & $36^{2}$ & $16^{2}$ \\
\hline & L2 & 136 & 103 & 33 & 26 & 7 \\
\hline & $\mathrm{L} 4$ & 4 & 3 & 1 & 0 & 1 \\
\hline \multirow[t]{3}{*}{ Behavior $(n)$} & B1 & 216 & 151 & $65^{1}$ & $48^{3}$ & 17 \\
\hline & B2 & 128 & 71 & 57 & 42 & 15 \\
\hline & B3 & 183 & 120 & 63 & 43 & 20 \\
\hline \multicolumn{2}{|c|}{ Perianal disease $n(\%)$} & $140(26.6)$ & $89(26.0)$ & $51(27.6)$ & $36(27.1)$ & $15(28.9)$ \\
\hline \multicolumn{2}{|c|}{ Frequent relapse $n(\%)$} & $195(37.1)$ & $126(36.9)$ & $69(37.3)$ & $47(35.3)$ & $22(42.3)$ \\
\hline \multicolumn{2}{|c|}{ Extraintestinal manifestations $n(\%)$} & ) 175 (33.2) & $117(34.2)$ & $58(31.3)$ & $45(33.8)$ & $13(25)$ \\
\hline \multicolumn{2}{|c|}{ Arthritis $n(\%)$} & $147(27.9)$ & $98(28.7)$ & $49(26.5)$ & $36(27.1)$ & $13(25)$ \\
\hline \multicolumn{7}{|l|}{ Erythema } \\
\hline \multicolumn{2}{|c|}{ nodosum/Pyoderma $n(\%)$} & $48(9.1)$ & $30(8.8)$ & $18(9.7)$ & $15(11.3)$ & $3(5.8)$ \\
\hline \multicolumn{2}{|c|}{$\mathrm{PSC}^{\mathrm{a}}$} & $18(3.4)$ & $15(4.4)$ & $3(1.6)$ & $3(2.3)$ & 0 \\
\hline \multirow{2}{*}{\multicolumn{2}{|c|}{$\begin{array}{l}\text { Steroid use/ } \\
\text { refractory } n(\%)\end{array}$}} & $440(83.5) /$ & $282(82.4) /$ & $158(85.4) /$ & $114(85.7) /$ & $44(84.6) /$ \\
\hline & & $44(10)$ & $28(9.3)$ & $16(10.1)$ & $10(8.8)$ & $6(13.6)$ \\
\hline \multirow{2}{*}{\multicolumn{2}{|c|}{$\begin{array}{l}\text { Azathioprine use/ } \\
\text { refractory } n(\%)\end{array}$}} & $337(64.1) /$ & $208(60.8) /$ & $129(69.7)^{1} /$ & $89(66.9) /$ & $40(76.9)^{4} /$ \\
\hline & & $19(5.6)$ & $10(4.8)$ & $9(7.0)$ & $7(7.8)$ & $2(5)$ \\
\hline \multicolumn{2}{|c|}{ Operation $n(\%)$} & $220(41.8)$ & $128(37.4)$ & $92(49.7)^{1}$ & $66(49.6)^{2}$ & $26(50.0)^{2}$ \\
\hline \multirow[t]{3}{*}{ Smoking $(n)$} & Never & 308 & 191 & 117 & 80 & 37 \\
\hline & Active & 170 & 115 & 55 & 42 & 13 \\
\hline & Previous & 49 & 36 & 13 & 11 & 2 \\
\hline
\end{tabular}

${ }^{1} P<0.03$ between carriers and non-carriers, ${ }^{2} P<0.03$ between patients carrying one or two mutant allele and non-carriers, ${ }^{3} P=0.043$ between patients carrying one mutant allele and non-carriers, ${ }^{4} P=0.025$ between patients carrying two mutant allele and non-carriers. 
Table 7 Genotype-phenotype associations with particular NOD2/CARD15 alleles in CD patients

\begin{tabular}{|c|c|c|c|c|c|}
\hline \multicolumn{2}{|l|}{ 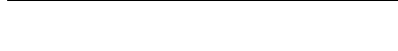 } & None $(n=342)$ & SNP8 $(n=61)$ & SNP12 $(n=33)$ & SNP13 $(n=102)$ \\
\hline \multicolumn{2}{|l|}{ Male/Female } & $174 / 168$ & $28 / 33$ & $14 / 19$ & $51 / 51$ \\
\hline \multicolumn{2}{|l|}{ Age (yr) } & $37.9 \pm 13.0$ & $35.9 \pm 13.0$ & $37.1 \pm 11.4$ & $33.7 \pm 10.4^{1}$ \\
\hline \multicolumn{2}{|c|}{ Duration (yr) } & $8.1 \pm 7.0$ & $9.3 \pm 7.6$ & $11.4 \pm 6.4^{2}$ & $7.7 \pm 6.1$ \\
\hline \multicolumn{2}{|c|}{ Familiar IBD $n(\%)$} & $38(11.1)$ & $9(14.8)$ & $7(21.1)$ & $11(10.8)$ \\
\hline \multirow[t]{3}{*}{ Location } & L1 & 84 & 16 & 7 & $32^{2}$ \\
\hline & L3 & 152 & 33 & 20 & 53 \\
\hline & $\mathrm{L} 4$ & 3 & 0 & 1 & 1 \\
\hline \multirow[t]{3}{*}{ Behavior } & B1 & 151 & 22 & 8 & 34 \\
\hline & B2 & 71 & 15 & 13 & 31 \\
\hline & B3 & 120 & 14 & 12 & 37 \\
\hline \multicolumn{2}{|c|}{ Perianal disease $n(\%)$} & $89(26.0)$ & $18(29.5)$ & $7(21.1)$ & $32(31.4)$ \\
\hline \multicolumn{2}{|c|}{ Frequent relapse $n(\%)$} & $126(36.9)$ & $24(39.3)$ & $13(39.4)$ & $38(37.3)$ \\
\hline \multicolumn{2}{|c|}{ Arthritis $n(\%)$} & $98(28.7)$ & $16(26.2)$ & $14(42.2)$ & $24(23.5)$ \\
\hline \multicolumn{2}{|l|}{ Occular $n(\%)$} & $18(5.2)$ & $1(1.6)$ & $2(6.1)$ & $4(3.9)$ \\
\hline \multicolumn{6}{|c|}{ Erythema nodosum/ } \\
\hline \multicolumn{2}{|c|}{ Pyoderma $n(\%)$} & $30(8.8)$ & $5(8.2)$ & $4(12.1)$ & $7(6.9)$ \\
\hline \multicolumn{2}{|l|}{$\operatorname{PSC} n(\%)$} & $15(4.4)$ & $1(1.6)$ & 0 & $2(1.9)$ \\
\hline \multicolumn{2}{|l|}{ Steroid use/ } & $282(82.4) /$ & $51(83.6) /$ & $31(93.9) /$ & $88(86.3) /$ \\
\hline \multicolumn{2}{|l|}{ refractory $n(\%)$} & $28(9.3)$ & $7(13.7)$ & $2(16.1)$ & $6(6.8)$ \\
\hline \multirow{2}{*}{\multicolumn{2}{|c|}{ Azathioprine use / refractory $n(\%)$}} & $208(60.8) /$ & $38(62.3) /$ & $32(97)^{1} /$ & $69(67.6) /$ \\
\hline & & $10(4.8)$ & $4(10.5)$ & $2(11.1)$ & $3(4.3)$ \\
\hline \multicolumn{2}{|l|}{ Operation $n(\%)$} & $128(37.4)$ & $27(44.3)$ & $23(69.7)^{1}$ & $53(52.0)^{2}$ \\
\hline \multirow[t]{3}{*}{ Smoking habits } & Never & 191 & 44 & 21 & 65 \\
\hline & Active & 115 & 12 & 9 & 33 \\
\hline & Previous & 36 & 5 & 3 & 4 \\
\hline
\end{tabular}

${ }^{1} P<0.001$ between carriers and non-carriers; ${ }^{2} P<0.03$ between carriers and non-carriers.

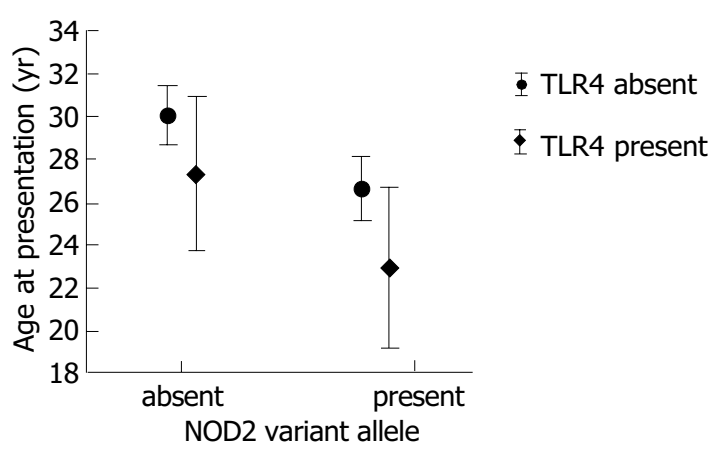

Figure 1 Association between genetics and age at presentation in patients with CD.

The TLR4 D299G mutation was not different between patients and controls ( $9.9 \%$ vs $12.0 \%, P=\mathrm{NS})$. The frequency of familial IBD tended to be lower in patients with TLR4 mutation (5.7\% vs without $12.6 \%, P=\mathrm{NS})$. However, the presence of variant TLR4 allele strengthened genotype-phenotype associations (Figure 1; for age of onset: non-carriers $[n=305]: 30.2$ years, only TLR 4 carriers $[n=37]: 27.4$ years, only NOD2/CARD15 carriers $[n=170]$ : 26.7 years, both NOD2 and TLR 4 carriers $[n=15]$ : 23 years, $P=0.03$ for NOD2/CARD15 variant allele, and $P=0.06$ for TLR4 variant allele by multiple regression and for ileal involvement; in patients with TLR4 and NOD2/CARD15 mutations: $86.7 \%$ vs non-carriers: $64.8 \%$ ).
In a logistic regression model, exploring the effect of NOD2, TLR4 carriage, age at presentation, location, behavior and smoking, presence of NOD2 mutation (coefficient $=$ $0.54, \mathrm{OR}=1.71,95 \% \mathrm{CI}: 1.13-2.62, P=0.01)$ and noninflammatory behavior (coefficient $=1.26, \mathrm{OR}=3.53$, 95\% CI: $2.76-4.51, P=0.001$ ) but not location, smoking or carriage of TLR4 variant allele were independently associated with the need for surgery. However, the percentage of multiple resections was not different between carriers and non-carriers $(13.0 \%$ vs $11.1 \%, P=\mathrm{NS})$.

\section{DISCUSSION}

This is the first report on the prevalence of NOD2/ CARD15 mutations and TLR4 D299G polymorphism in patients with CD from a Central Eastern European country. The reported rates of $35.1 \%$ of patients carrying NOD2/ CARD15 mutations in CD and $16.5 \%$ in controls are in concordance with previously reported rates of $30-50 \%$ in $\mathrm{CD}$ and $7-20 \%$ in controls from other European regions ${ }^{[12,15-17,32-35]}$. Only in Finland (which by language is related to Hungary), the rate of NOD2 mutations was considerably lower $(8.7 \% \text { vs } 3.5 \% \text { in controls })^{[21]}$. Similar low frequencies were found in other Northern European countries $(8 \%$ in Denmark, and $8.9 \%$ in patients from Norway) ${ }^{[28]}$. The prevalence of SNP8, 12 and 13 was 3.3, 0.6 and $4.8 \%$ in the Finish study (in controls it was 1.8\%, 0 and $1.7 \%$ ) with only the SNP13 being more common in CD compared to controls. In our study, the rates were 11.6, 
6.3 and $19.4 \%$, which are in concordance with other studies from Europe $(6.7-12.5 \%, 3.3-6.1 \%$ and $6.6-16 \%$ in CD and $3.5-6.9 \%, 0.6-3.0 \%$ and $1.0-4.4 \%$ in controls $)^{[17,33]}$.

The phenotype-genotype correlations in our cohort were also similar to those reported in various European countries $^{[6,17,36]}$. Ileal involvement in Hungarian patients was more frequent in NOD2 mutation carriers (81.6\%), while disease confined to the colon alone was less frequent $(17.8 \%)$, especially in patients with two alleles, in the presence of SNP13 or TLR4 variant allele. Like in other countries, in our study, carriage of variant NOD2/CARD15 allele was associated with stricturing disease (30.8\% vs 20.8\%), while variant alleles were less frequent in patients with inflammatory disease. More patients with stricturing disease carried a mutant NOD2/CARD15 allele (44.5\%) than patients without strictures $(32.1 \%, P<0.01)$. Steroid use and efficacy were similar in mutation carriers and non-carriers, but a higher percentage of patients carrying NOD2/CARD15 variant allele needed azathioprine during the course of the disease, especially in the presence of two risk alleles. There are conflicting data on the association of NOD2/CARD15 mutations and need for surgery in CD patients: association ${ }^{[37]}$ and also lack of association ${ }^{[16,17]}$ have been reported.

In a French follow-up study ${ }^{[18]}$, ileal location was associated with early development of stricturing disease while a high number of flares was associated with a penetrating pattern, but this was not affected by the presence of variant NOD2/CARD15 allele. Active smoking was also associated with early development of penetrating disease. In our study there was no difference in the proportion of smokers between carriers and non-carriers of NOD2/CARD15 variant allele.

The importance of TLR4 D299G polymorphism in CD is less clear. In contrast to Franchimont et al. ${ }^{[27]}$ who reported a two-fold elevation in allele frequency of TLR4 D299G $(11 \%$ vs $5 \%$, OR $=2.31)$, we found no difference in the prevalence of TLR4 D299G polymorphism in CD patients and controls, suggesting that this polymorphism is not essential in the development of the disease. There is also no difference in TLR4 allele frequency between IBD patients and controls in concordance with the preliminary results of the EC-IBD study group ${ }^{[28]}$. However, the rate of variant allele is higher in the Hungarian controls compared to the study of Franchimont et al. ${ }^{[27]}$. We also found a tendency of decreased frequency of the TLR4 D299G variant allele in patients with familial disease $(6 \% v s$ sporadic $13 \%, P=\mathrm{NS})$.

In our study, no clear-cut phenotype-genotype associations were observed in TLR4 D299G carriers. The presence of variant TLR 4 allele tendencially associated with early disease onset $(P=0.06)$, along with a gene-dosage effect. The earliest onset (23 years) was observed in carriers of both variant NOD2/CARD15 and TLR4 alleles ( $v$ s noncarriers 30.2 years, $P=0.01)$. The presence of TLR 4 variant allele did not affect disease behavior (in patients with variant TLR4 allele, stricturing disease was present in $33.3 \%$ of NOD2 carriers $v s$ 17.1\% of NOD2/CARD15 non-carriers).

In summary, this is the first report on the prevalence of NOD2/CARD15 mutations and TLR4 D299G polymorphism in patients with CD from a Central Eastern European country. It confirms that the risk for $\mathrm{CD}$ is increased in carriers of R702W, R703C and 3020insC mutations, while the presence of G908R or TLR4 D299G polymorphism is not different from the controls. The presence of variant NOD2/CARD15 alleles is associated with early disease onset, ileal disease and stricturing disease behavior and increases need for surgery, while the presence of TLR4 D299G variant allele exhibits a disease modifier effect.

\section{ACKNOWLEDGEMENTS}

The authors thank Dr. Peter Vargha for performing the statistical analysis.

\section{REFERENCES}

1 Podolsky DK. Inflammatory bowel disease. N Engl J Med 2002; 347: 417-428

2 Lakatos L, Mester G, Erdelyi Z, Balogh M, Szipocs I, Kamaras G, Lakatos PL. Striking elevation in incidence and prevalence of inflammatory bowel disease in a province of western Hungary between 1977-2001. World J Gastroenterol 2004; 10: $404-409$

3 Hugot JP, Laurent-Puig P, Gower-Rousseau C, Olson JM, Lee JC, Beaugerie L, Naom I, Dupas JL, Van Gossum A, Orholm M, Bonaiti-Pellie C, Weissenbach J, Mathew CG, Lennard-Jones JE, Cortot A, Colombel JF, Thomas G. Mapping for susceptibility locus for Crohn's disease on chromosome 16. Nature 1996; 379: 821-823

4 Colombel JF. The CARD15 (also known as NOD2) gene in Crohn's disease: Are there implications for current clinical practice? Clin Gastroenterol Hepatol 2003; 1: 5-9

5 Bonen DK, Cho JH. The genetics of inflammatory bowel disease. Gastroenterology 2003; 124: 521-536

6 Ahmad T, Tamboli CP, Jewell DP, Colombel JF. Clinical relevance of advances in genetics and pharmacogenetics of IBD. Gastroenterology 2004; 128: 1533-1549

7 Berrebi D, Maudinas R, Hugot JP, Chamaillard M, Chareyre F, De Lagausie P, Yang C, Desreumaux P, Giovannini M, Cezard JP, Zouali H, Emilie D, Peuchmaur M. CARD15 gene overexpression in mononuclear and epithelial cells of the inflamed Crohn's disease colon. Gut 2003; 52: 840-846

8 Girardin SE, Hugot JP, Sansonetti PJ. Lessons from Nod2 studies: towards a link between Crohn's disease and bacterial sensing. Trends Immunol 2003; 24: 652-658

9 Bonen DK, Ogura Y, Nicolae DL, Inohara N, Saab L, Tanabe T, Chen FF, Foster SJ, Duerr RH, Brant SR, Cho JH, Nunez G. Crohn's disease-associated NOD2 variants share a signaling defect in response to lipopolysaccharide and peptidoglycan. Gastroenterology 2003; 124: 140-146

10 Aldhous MC, Nimmo ER, Satsangi J. NOD2/CARD15 and the Paneth cell: another piece in the genetic jigsaw of inflammatory bowel disease. Gut 2003; 52: 1533-1535

11 Girardin SE, Boneca IG, Viala J, Chamaillard M, Labigne A, Thomas G, Philpott DJ, Sansonetti PJ. Nod2 is a general sensor of peptidoglycan through muramyl dipeptide (MDP) detection. J Biol Chem 2003; 278: 8869-8872

12 Hugot JP, Chamaillard M, Zouali H, Lesage S, Cezard JP, Belaiche J, Almer S, Tysk C, O'Morain CA, Gassull M, Binder V, Finkel Y, Cortot A, Modigliani R, Laurent-Puig P, GowerRousseau C, Macry J, Colombel JF, Sahbatou M, Thomas G. Association of NOD2 leucine-rich repeat variants with susceptibility to Crohn's disease. Nature 2001; 411: 599-603

13 Ogura Y, Bonen DK, Inohara N, Nicolae DL, Chen FF, Ramos R, Britton H, Moran T, Karaliuskas R, Duerr RH, Achkar JP, Brant SR, Bayless TM, Kirschner BS, Hanauer SB, Nunez G, Cho JH. A frameshift mutation in NOD2 associated with susceptibility to Crohn's disease. Nature 2001; 411: 603-606

14 Hampe J, Cuthbert A, Croucher PJ, Mirza MM, Mascheretti S, Fisher S, Frenzel H, King K, Hasselmeyer A, MacPherson AJ, Bridger S, van Deventer S, Forbes A, Nikolaus S, Lennard- 
Jones JE, Foelsch UR, Krawczak M, Lewis C, Schreiber S, Mathew CG. Association between insertion mutation in NOD2 gene and Crohn's disease in German and British populations. Lancet 2001; 357: 1925-1928

15 Ahmad T, Armuzzi A, Bunce M, Mulcahy-Hawes K, Marshall SE, Orchard TR, Crawshaw J, Large O, de Silva A, Cook JT, Barnardo M, Cullen S, Welsh KI, Jewell DP. The molecular classification of the clinical manifestations of Crohn's disease. Gastroenterology 2002; 122: 854-866

16 Brant SR, Picco MF, Achkar JP, Bayless TM, Kane SV, Brzezinski A, Nouvet FJ, Bonen D, Karban A, Dassopoulos T, Karaliukas R, Beaty TH, Hanauer SB, Duerr RH, Cho JH. Defining complex contributions of NOD2/CARD15 gene mutations, age at onset, and tobacco use on Crohn's disease phenotypes. Inflamm Bowel Dis 2003; 9: 281-289

17 Lesage S, Zouali H, Cezard JP, Colombel JF, Belaiche J, Almer S, Tysk C, O'Morain C, Gassull M, Binder V, Finkel Y, Modigliani R, Gower-Rousseau C, Macry J, Merlin F, Chamaillard M, Jannot AS, Thomas G, Hugot JP. CARD/ 15/NOD2 mutational analysis and genotype-phenotype correlation in 612 patients with inflammatory bowel disease. Am J Hum Genet 2002; 70: 845-857

18 Louis E, Michel V, Hugot JP, Reenaers C, Fontaine F, Delforge M, El Yafi F, Colombel JF, Belaiche J. Early development of stricturing or penetrating pattern in Crohn's disease is influenced by disease location, number of flares, and smoking but not by NOD2/CARD15 genotype. Gut 2003; 52: 552-557

19 Inoue N, Tamura K, Kinouchi Y, Fukuda Y, Takahashi S, Ogura Y, Inohara N, Nunez G, Kishi Y, Koike Y, Shimosegawa $\mathrm{T}$, Shimoyama T, Hibi T. Lack of common NOD2 variants in Japanese patients with Crohn's disease. Gastroenterology 2002; 123: $86-91$

20 Leong RW, Armuzzi A, Ahmad T, Wong ML, Tse P, Jewell DP, Sung JJ. NOD2/CARD15 gene polymorphisms and Crohn's disease in the Chinese population. Aliment Pharmacol Ther 2003; 17: 1465-1470

21 Helio T, Halme L, Lappalainen M, Fodstad H, Paavola-Sakki P, Turunen U, Farkkila M, Krusius T, Kontula K. CARD15/ NOD2 gene variants are associated with familially occurring and complicated forms of Crohn's disease. Gut 2003; 52: 558-562

22 Hornef MW, Normark BH, Vandewalle A, Normark S. Intracellular recognition of lipopolysaccharide by toll-like receptor 4 in intestinal epithelial cells. J Exp Med 2003; 198: 1225-1235

23 Ruemmele FM, Beaulieu JF, Dionne S, Levy E, Seidman EG, Cerf-Bensussan N, Lentze MJ. Lipopolysaccharide modulation of normal enterocyte turnover by toll-like receptors is mediated by endogenously produced tumour necrosis factor a. Gut 2002; 51: $842-848$

24 Boone DL, Ma A. Connecting the dots from Toll-like receptors to innate immune cells and inflammatory bowel disease. J Clin Invest 2003; 111: 1284-1286

25 Cario E, Podosky DK. Differential alteration in intestinal epithelial cell expression of Toll-like receptor 3 (TLR3) and TLR4 in inflammatory bowel disease. Infect Immun 2000; 68: 7010-7017

26 Okayama N, Fujimura K, Suehiro Y, Hamanaka Y, Fujiwara
M, Matsubara T, Maekawa T, Hazama S, Oka M, Nohara H, Kayano K, Okita K, Hinoda Y. Simple genotype analysis of the Asp299Gly polymorphism of the Toll-like receptor-4 gene that is associated with lipopolysaccharide hyporesponsiveness. J Clin Lab Anal 2002; 16: 56-58

27 Franchimont D, Vermeire S, El Housni H, Pierik M, Van Steen K, Gustot T, Quertinmont E, Abramowicz M, Van Gossum A, Deviere J, Rutgeerts P. Deficient host-bacteria interactions in inflammatory bowel disease? The toll-like receptor (TLR)-4 Asp299gly polymorphism is associated with Crohn's disease and ulcerative colitis. Gut 2004; 53: 987-992

28 Riis LB, Wolters F, Solberg C. Regional differences in the prevalence of single nucleotide polymorphisms in CARD15/ NOD2 but not in toll-like receptor 4 (TLR4) Asp299Gly polymorphism in patients with inflammatory bowel disease (IBD) across Europe: Results from the EC-IBD study group. Gastroenterology 2004; 126(Suppl S): M1539

29 Lennard-Jones JE. Classification of inflammatory bowel disease. Scand J Gastroenterol Suppl 1989; 170: 2-6

30 Gasche C, Scholmerich J, Brynskov J, D'Haens G, Hanauer SB, Irvine EJ, Jewell DP, Rachmilewitz D, Sachar DB, Sandborn WJ, Sutherland LR. A simple classification of Crohn's disease: Report of the Working Party for the World Congresses of Gastroenterology, Vienna 1998. Inflamm Bowel Dis 2000; 6: 8-15

31 Lorenz E, Frees KL, Schwartz DA. Determination of the TLR4 genotype using allele-specific PCR. Biotechniques 2001; 31: $22-24$

32 Annese V, Palmieri O, Latiano A, Ardizzone S, Castiglione F, Cottone M, D'Inca R, Gionchetti P, Papi C, Riegler G, Vecchi $\mathrm{M}$, Andriulli A. Frequency of NOD2/CARD15 variants in both sporadic and familial cases of Crohn's disease across Italy. An italian group of inflammatory bowel disease study. Dig Liver Dis 2004; 36: 121-124

33 Cuthbert AP, Fisher SA, Mirza MM, King K, Hampe J, Croucher PJ, Mascheretti S, Sanderson J, Forbes A, Mansfield J, Schreiber S, Lewis CM, Mathew CG. The contribution of NOD2 gene mutations to the risk and site of disease in inflammatory bowel disease. Gastroenterology 2002; 122: 867-874

34 Abreu MT, Taylor KD, Lin YC, Hang T, Gaiennie J, Landers CJ, Vasiliauskas EA, Kam LY, Rojany M, Papadakis KA, Rotter JI, Targan SR, Yang H. Mutations in NOD2 are associated with fibrostenosing disease in patients with Crohn's disease. Gastroenterology 2002; 123: 679-688

35 Heresbach D, Gicquel-Douabin V, Birebent B, D'halluin PN, Heresbach-Le Berre N, Dreano S, Siproudhis L, Dabadie A, Gosselin M, Mosser J, Semana G, Bretagne JF, Yaouanq J. NOD2/CARD15 gene polymorphisms in Crohn's disease: A genotype-phenotype analysis. Eur J Gastroenterol Hepatol 2004; 16: 55-62

36 Torok HP, Glas J, Lohse P, Folwaczny C. Alteration of the CARD15/NOD2 gene and the impact on management and treatment of Crohn's disease patients. Dig Dis 2003; 21: 339-345

37 Buning C, Genschel J, Buhner S, Kruger S, Kling K, Dignass A, Baier P, Bochow B, Ockenga J, Schmidt HH, Lochs H. Mutation in the NOD2/CARD15 gene in Crohn's disease are associated with ileocecal resection and are a risk factor for reoperation. Aliment Pharmacol Ther 2004; 19: 1073-1078

Edited by Wang XL and Guo SY Language Editor Elsevier HK 